\title{
ECONOMIC EVALUATION OF THE SHEEP FARM OF BLACK-HEADED PLEVEN SHEEP IN THE VILLAGE OF HITRINO, SHOUMEN DISTRICT
}

\author{
K. Stankov \\ Trakia University, Stara Zagora, Bulgaria
}

\begin{abstract}
The aim of the present study is to perform an economic evaluation of a sheep farm in a herd under the control of the Sheepdog Shepherd in the village of Hitrino, Shumen district. The herd consists of 234 sheep, incl. 170 ewes, 6 males and 60 females. Milk for a dairy ewe period is 92 liters, and fertility 1.3 lambs. Productivity, revenue and expenditure data is taken from the farm accountancy data. Data processing is based on the mathematical and statistical model of an Excel computer program. Revenue from milk accounted for $38.5 \%$ of the total share, and $59.86 \%$ for meat. Wool is bought at very low prices and takes a negligible share of revenue. Variable costs accounted for $55.9 \%$ and fixed $44.1 \%$. The main share of the variable costs is taken by the feed, which accounts for $78.72 \%$ of these and $44 \%$ of the total costs. $91.77 \%$ of fixed costs are for labor and their share is $40.47 \%$ of total costs. The subsidies amounted to BGN 140 and with them the revenues increased by $31.9 \%$ and contributed to the closing of BGN 58.29 profit from the sheep-mother, while without them the farm ended with a loss of 81.71 BGN. Profitability with subsidies is $+13.29 \%$ and no subsidies $-27.38 \%$. Subsidies are + $15.33 \%$, and without subsidies $-21.49 \%$. The results of the study show that, without providing subsidies, sheep of the Blackheaded Sheep Sheep are ending up with a loss.
\end{abstract}

Keywords: economic evaluation, sheep breeding, productivity, profitabitability

The Black-headed Pleven Sheep is the most popular Bulgarian autochthonous breed. It was created in Northern Bulgaria, mainly in the Pleven region through folk selection. It is believed that there is blood from the most milky breed in the world - East Frisian (1).

Georgiev (2) points out that Black-headed sheep are the largest domestic sheep in our country. They are tall, long and with dry body shapes. The sheep of the breed have the highest milk yield of all local breeds in our country. For a lactation period of $180-200$ days, the average milk yield is $150-160 \mathrm{~kg}$. milk. The maximum milk yield is $472 \mathrm{~kg}$. Fertility is also high $-150-160 \%$.

Todorov (3) indicates that the Black-headed Pleven breed has a much higher potential for milkiness and fertility. This, in addition to purposeful selection, can be achieved through proper and complete nutrition. The studies of Vitkov (4) and Tsvetanov (1988), Georgiev (5), Panayotov and Simeonov (6), Nedyalkov (7) et al. show that the reasons for the unfulfilled potential for milkiness and fertility are to a great extent in the non-genetic factors, especially nutrition.

Boykovski and Georgiev (8) found that the inheritance coefficient for fertility was much lower and selection for this trait would not be effective for mass breeding.

Increasing the economic efficiency and competitiveness of Bulgarian sheep breeding is one of the most important tasks of the executive power and non-governmental organizations. This is possible through the maximum use of genetic potential, modern technological methods - of feeding, milking, fertilization, as well as the introduction of modern organizational forms, which were excluded in small and medium-sized farms during the transition period (9-11).

These are the recommendations made by the European Parliament in May 2018.

The purpose of this study is to evaluate economically a flock of sheep under breeding 
control of a black-headed weed breed and to take into account the impact of subsidization,

\section{MATERIAL AND METHODS}

The object of this study is the sheep farm in Hitrino village, Shoumen district. The herd consists of 234 sheep, including 170 ewes, 6 rams and 60 ewe-lambs. This is a typical herd that can be considered as an average statistic for Bulgarian dairy sheep.

The sheep are reared grazing. During the grazing period, which lasts until late autumn, the sheep are grazed on pastures provided by the municipal lease fund. Feed for the rearing period is self-produced and includes concentrated feed, alfalfa hay, straw, mineral and protein additives. The milking of the sheep is doubled with milking dumplings.

The farm is family owned and served mainly by the family and a year-round sheep breeder.
In addition to servicing the herd, those involved in the production activity of the farm are also engaged in the production of feed for the feeding of the herd during the breeding period.

Productivity, revenue and cost data are taken from farm accounting. Revenues and expenses are valued at current prices. The profit and the rate of profitability of the revenue, as well as the costs in percentages, were calculated, comparing the data with subsidies and without subsidies. All calculations are attributed to a single Ewe.

Data processing is according to the mathematical-statistical model through a computer program Excel.

\section{RESULTS AND DISCUSSION}

Table 1 provides data on sheep numbers and herd structure.

Table 1. Data on the sheep farm in the village of Hitrino, Shoumen district

\begin{tabular}{|l|c|c|}
\hline Indicators & Measuring units & Data \\
\hline Ewes & Number & 170 \\
\hline Rams & Number & 6 \\
\hline Ewe lambs & Number & 60 \\
\hline Born lambs & $\%$ & 142 \\
\hline Weaned lambs & $\%$ & 130 \\
\hline Lactation duration - average & Days & 208 \\
\hline Milking period - days & Days & 142 \\
\hline Milkiness for the milking period & Litres & 92 \\
\hline Average daily milkiness & Litres & 0,648 \\
\hline
\end{tabular}

The data shows that the biological fertility of the herd is $142 \%$, and the economic one is judged by the number of weaned lambs $130 \%$. The difference of $12 \%$ is from dead and killed lambs as needed, which indicates that there are problems with protecting the lambs until weaning. The herd's potential for higher fertility is greater, which necessitates better training of the ewes for the campaign.

The lactation duration averages 208 days and the milking period 142. Data indicate that the milking period is relatively short for a dairy herd, leading to significant losses from milk not sold by dairies. The later start of milking from the beginning of April to the middle of August deprives the farm of about $50 \%$ of the sheep's milk. At the onset of lactation in the sheep, the lactation curve is highest and malnutrition in the sheep during this period is a loss of milk. This is due to the problems created by the purchasers of sheep's milk with the refusal of the earlier start and also the very early cessation of its purchase. This problem, which has been repeated for years, can only be solved by the creation of groups of producer organizations, the creation of mini dairies and the shortening of the milk chain. Artificial mothers are already creating good opportunities, which presupposes the early weaning of the lambs.

Table 2 presents data on the natural performance of the sheep farm attributed to the ewe.

The milk obtained for the milking period is 92 liters, which is well below the breed's capacity. The purchase price is BGN 1.25 per liter of milk and is significantly lower than previous years when sheep's milk was bought for BGN 1.40. This way sheep's milk, which should be a leader in a dairy farm, accounts for only $38.5 \%$ of revenue. The meat of lambs sold for meat and breeding and adult scrap sheep accounted 
STANKOV K.

for $59.9 \%$, which is a relatively good indicator, but not entirely logical for dairy sheep. Wool is bought at almost nothing and leads to farm losses because sometimes the cost of cutting an animal is higher than the cost of the wool.

Table 2. Natural and value indicators of the farm in the village of Hitrino.

\begin{tabular}{|l|c|c|c|}
\hline Indicators & Quantity & Average price & Total amount BGN. \\
\hline $\begin{array}{l}\text { Quantity milk for a } \\
\text { milking period, } 1 .\end{array}$ & 92 & 1,25 & 115 \\
\hline $\begin{array}{l}\text { Market lambs, kg. from } \\
\text { one Ewe, kg. }\end{array}$ & 39 & 5,25 & 157,5 \\
\hline $\begin{array}{l}\text { Discarded sheep sold } \\
\text { (relative share to the } \\
\text { herd), kg. }\end{array}$ & 14,11 & 1,50 & 21,18 \\
\hline Wool, kg, & 1,20 & 1,50 & 4,80 \\
\hline $\begin{array}{l}\text { Breeding Control } \\
\text { Subsidy - 2018 }\end{array}$ & 1 & 15,00 & 75,00 \\
\hline $\begin{array}{l}\text { Subsidy } \\
\text { DE Minimis }\end{array}$ & 1 & 33 & 15 \\
\hline Humane treatment & & & 298,48 \\
\hline $\begin{array}{l}\text { Pasture maintenance } \\
\text { subsidy, ha }\end{array}$ & 17 & 438,48 \\
\hline $\begin{array}{l}\text { Total amount without } \\
\text { subsidy }\end{array}$ & & & \\
\hline $\begin{array}{l}\text { Oбща cyмa cъc } \\
\text { cyбсидия } \\
\text { Total amount with } \\
\text { subsidy }\end{array}$ & & & \\
\hline
\end{tabular}

The data also show that the problem of farm income is solved by a subsidy, which, when included, provides an additional $31 \%$ of total revenue.
Table 3 shows that the production costs of the Black-headed Pleven sheep breed amount to 380.19 BGN. The variable costs occupy $55.90 \%$ and the constant $44.10 \%$.

Table 3. Production costs of sheep from Black-headed Pleven Sheep in the farm of the village of Hitrino.

\begin{tabular}{|l|r|r|r|}
\hline Indicators & Value, BGN & $\begin{array}{l}\text { In\% of variables and } \\
\text { constants }\end{array}$ & \% Of total cost \\
\hline $\begin{array}{c}\text { Variable } \\
\text { costs }\end{array}$ & & & \\
\hline Total variables & 212,54 & 100,00 & 55,90 \\
\hline Feed & 167,30 & 78,72 & 44,00 \\
\hline Veterinary services & 5,00 & 2,35 & 1,32 \\
\hline Fuels & 24,04 & 11,31 & 1,32 \\
\hline Water, electricity & 7,50 & 3,53 & 2,29 \\
\hline External services & 8,70 & 4,09 & 44,10 \\
\hline \multicolumn{1}{|c|}{ II. Fixed costs } & 167,65 & 100,00 & 0,47 \\
\hline Tруд Labour & 153,85 & 91,77 & 3,39 \\
\hline Сгради Buildings & 1,50 & 0,89 & \\
\hline Machines & 12,30 & 7,34 & \\
\hline All production costs & 380,19 & & \\
\hline
\end{tabular}

Of all expenditures, labor and feed, with almost the same percentage, account for the highest relative share. Other costs account for a small share. Similar results were obtained by Slavova et al. (12), who find that in the Synthetic population, Bulgarian milk has the highest relative share of wage and insurance costs - between $42-46 \%$, followed by feed costs $-40 \%$.

Farm production costs may be considered optimal for farm analysis, but when feed levels 
are increased and wages are paid, which would be normal and stimulating productivity, their size should be increased. This can only be achieved if milking over 150 liters is increased for milking and a normal milk purchase price is between BGN 1.40-1.50/1, and sheep fertility is increased. Achieving these goals is quite possible with the cooperation of the sheep breeders, the pooling of resources, the closure of the production cycle and the direct sale of the sheep breeding products.

The data in Table 4 clearly show the actual state of the farm, and thus the condition of all Bulgarian mid-range sheep farms.

Table 4. Profitability of the income and expenses of a sheep farm in the village of Hitrino, Shoumen district.

\begin{tabular}{|l|c|}
\hline Indicators for Ewes & BGN, percent \% \\
\hline Income without subsidy Income without subsidy & 438,48 \\
\hline Income without subsidy & 298,48 \\
\hline Costs & 380,19 \\
\hline Profit with subsidy & 58,29 \\
\hline Profit without subsidy & $-81,71$ \\
\hline Profitability of revenues with subsidies & $+13,29$ \\
\hline Profitability of revenues without subsidies & $-27,38$ \\
\hline Cost effectiveness with subsidies & $+15,33$ \\
\hline Cost-effectiveness without subsidies & $-21,49$ \\
\hline
\end{tabular}

Without subsidizing the farms at relatively low sheep productivity and unsatisfactory technological levels, as well as without the horizontal and vertical integration of sheep farmers in Bulgaria, sheep breeding will continue to be a loss. This is precisely what necessitates the development of strategic guidelines for its further development in a market economy, and the technical and technological upgrading of the sector. We need to draw on their experience and restore the leading positions of Bulgarian sheep breeding. Of interest are the ideas of Slovak researchers who have made significant progress in dairy farming and the experience of neighboring Greece, which has become one of the leading sheep countries, and especially in organic production.

Michalickova et al. (13) consider that sheep productivity, the market price of their products, feed prices, labor and other direct costs, and depreciation and the amount of subsidies are determining factors for cost effectiveness in dairy sheep.

Krupová et al. (14) examine the economic values of 14 productive and functional traits in two breeds of sheep for milk in Slovakia and find that milk for the milking period is the trait with the greatest relative impact on profit, followed by the duration of economic use and fertility rates. sheep.
Economic Evaluation of Conventional and Organic Sheep Breeding in Greece by Stochastic Performance Analysis is made by Irene Tzoutramani (15) et al. The results show that organic farming relies mainly on organic payments, and conventional farming generates a net profit.

\section{CONCLUSION}

The results of the investigations justify the following important conclusions.

A higher economic effect than the Blackheaded Pleven sheep can be obtained if targeted breeding and milking are carried out, and only high-breeding flocks are used for breeding herds.

Dairy sheep can reach their genetic potential if adequate nutrition is provided with quality feed mixtures, alfalfa hay and provided in sufficient quantities of succulent fodder during the lactation period.

Better integration between producers, processors and traders is imperative, and the contract guarantees the purchase of products throughout the entire production cycle at costeffective prices and ensuring profits.

Continue work on building organizations and producer groups that will allow for pooling of resources, technical and technological upgrades, construction of small processing plants and direct products. 


\section{REFERENCES}

1. Raichev, St. 1988. Sheep Breeding in Bulgaria, VIZVM, Stara Zagora, 1-29.

2. Georgiev, D. 2012. Facebook.com/server.bg.

3. N. Todorov, A. Alexandrov. 2013. How to make dairy farming more profitable., Sofia, 5-95.

4. Vitkov, V. 1987. Zootechnical Characteristics of the Productivity of Milk Sheep from the Black-headed Pleven and its Avasi at an Equally Changing Diet. Dissertation - Sofia, 153.

5. Georgiev, D. 1990- Genetic structure, phenotypic and genotypic characteristics of the breeding traits of sheep from the Blackheaded Pleven breed following the example of the herd of Riben village at the G. Dimitrov PA near Pleven. Thesis, Sofia. SAA, Institute of Animal Breeding with Center for Biotechnology, Shumen.

6. Panayotov, D., M. Simeonov, 2008. Study on the live weight and fertility of sheep from the Pleven Black-headed breed. Animal Science, 4, 25-29.

7. Nedyalkov, Kr., M. Simeonov, N. Todorov, G. Ganchev. 2015. Influence of some nongenetic factors on fertility in sheep of the Black-headed Pleven breed. Animal Science, LII, 4, 3-10.

8. Boykovski, S., D. Georgiev. 2005. Blackheaded Pleven Sheep. June Express Publishers, Shumen.

9. Tiankov, St., Il.Dimitrov, Iv.Stankov, R. Slavov, D. Panayotov, I. Georgiev, G. Kabov 1997. Livestock breeding in Bulgaria on the eve of the third millennium. State, Problems, Prospects, Stara Zagora, 23-38.

10. Atanasova, T. 2002. Abstract of dissertation. Analysis and evaluation of the legal and organizational forms of agricultural enterprises following the example of Stara Zagora District, Sofia, 1132.

11. Stankov, I. and qty. 2014. National Strategy for the Sustainable Development of Agriculture in Bulgaria in the Period 2014-20120, Sofia, 231-250.

12. Slavova, V., N.Stancheva, V.Laleva, Y.Popova, P.Slovova. Economic efficiency of the flock of sheep from the Synthetic Bulgarian Dairy Population reared in the EB-DP at ZI - Shumen, Tzarev Brod. Animal Science, LII, 5, 90-97.

13. Michlickova, M., Z. Krupová, E.Krupa. 2014. Determinations of economics efficiency in dairy cattle and sheep. Slovak J. Anim.Sci., 47, 2014 (1): 39-50.

14. Krupová, Z., M.Wolfovál, Z.Wolfl.M, M.Oranková, M.Mrgetin, D.Peskovizová, E. Krupova and Z.Dano. 2009. Economic Values for Dairy Sheep Breeds in Slovakia Asian-Aust. J. Anim.Sci., Vol.22, No. 12, 1693-1702.

15. Stankov, I. and qty. 2002. Problems of livestock production in the Republic of Bulgaria. Applied Science Conference, 783.

16. Todorov, N. 2007. Proper nutrition is the basis for increasing farm productivity and efficiency. Sheep breeding in our country and in Europe. Sat. With reports from scientific conferences, Enievche Publishing House, 143-152.

17. Abd-Allan, M., S.Abass and F.Allam. 2011. Reproductive performance of Bahman and chose sheep and their lambs under upper Egyptian conditions. Online Journal of Animal and Feed Research, 1 (3): 121-129.

18. Tzoutramani, I., A.Sintori, A., A.Liontakis, P.Karanikolos, G.Alexoloulas. 2011. An assessment of the economic performance of organic dairy sheep farming in Greece. Livestock stock science, vol.141, Issues 2-3, 136-142. 